\title{
Simscape Based Modelling \& Simulation of MPPT Controller for PV Systems
}

\author{
Gunjan Varshney ${ }^{1}$, D.S. Chauhan ${ }^{2}$, M.P. Dave ${ }^{3}$ \\ ${ }^{I}$ (Research Scholar, Department of Electrical Engineering Uttarakhand Technical University Dehradun, India) \\ ${ }^{2}$ (Department of Electrical Engineering GLA University Mathura, India) \\ ${ }^{3}$ (Department of Electrical Engineering AKGEC Ghaziabad, India)
}

\begin{abstract}
In modern time electricity demand is increasing day by day and due to limitations of fossil fuels and other environmental issues the whole world is looking for alternatives. Renewable energy sources are proving their strength. Solar energy is the most important renewable and sustainable energy system. The modelling of solar cell and array is very much time consuming because it has so many complex mathematical equations. Sometimes we need only the solar cell for its applications without going into details of its complex equations. MATLAB has provided a very helpful and handy tool for solar cell in Simscape library that uses the physical language for modelling. But before using that tool It becomes necessary to learn the interfacing between Simscape and SPS tools with the use of some converters. In this paper step by step procedure is shown for modelling of solar array with the use of Simscape library. To extract the Maximum power from solar array, MPPT technique is necessary so in this paper Incremental conductance method is used for MPPT and results are shown in the form of various characteristics of solar array.
\end{abstract}

Keywords: Maximum Power Point (MPPT), Photovoltaic (PV), PV Array, Simscape.

\section{Introduction}

Renewable Sources of Energy witnessed a widespread increase in their use throughout the globe during the $21^{\text {st }}$ century due to non availability and shortages of fossil fuels and other conventional form of energy and their inability to meet up for the ever increasing power demand due to increase in population. Thus, it called for exploitation of the massive potential in renewable energy technology so as to cope up with these problems. Solar Energy is the most important renewable and sustainable energy system. Solar-Electric-Energy system has grown consistently and is seen as the chief renewable energy source utilized due to increase in efficiency of solar cells and recent technological improvements. Solar Cell efficiencies now have been found out to be in the range of $12 \%-20 \%$, Therefore, to preserve this little harvested energy, the whole system such as energy conversion stage has to be designed carefully and efficiently.

Solar Cells or Photo Voltaic Cells are devices or we can say transducers that convert the energy available from sunlight directly into electrical energy which is DC in its nature. PV Cells are based on the principle of photoelectric effect. PV Cell as the single unit generates a very small amount of voltage in the range of 0.5 to $0.8 \mathrm{~V}$ depending upon the technology which is being used. For commercial use these cells are connected or integrated in series and parallel to form a PV array in order to give a decent amount of voltage which could find some application in the commercial world. Experimenting with PV Cells in actual is not an easy task as it consumes too much of time and money, that is where PC based simulation and data acquisition software comes into the picture, for example Matlab/Simulink and Pspice[2,3]. In this paper we have made a combined use of Simscape library - in which we did physical modelling and Simulink in Matlab for software. Although there used to be a requirement to do the cumbersome coding and modelling of the PV cell in MATLAB, but MATLAB 2010 has the feature of an in-built PV Cell Block in Simscape[1], which represents a single solar cell as a parallel current source $\mathrm{I}_{\mathrm{ph}}$, an exponential diode $\mathrm{D}$ and a shunt resistance $\mathrm{R}_{\mathrm{sh}}$ that are connected in series with a resistance $R_{s}$. A Solar Array was constructed by making use of series-parallel connection of available solar cell blocks in the Simscape library. For the PV panel to operate at maximum power a maximum power point tracker (MPPT) was modelled and connected to PV panel. The method used for tracking the maximum power point is incremental conductance method. The programming of MPPT was done in embedded function of the MATLAB.

\section{PV Cell and PV Array}

\section{A. PV Cell}

The Solar Cell Block in Simscape [1] has 3 terminals, one is for the irradiance to be given to the cell and the other 2 are simply the positive and negative terminals of the cell for current to flow across it as shown in figure 1. 


\section{B. Solar Cell Model}

The Solar Cell Model[7,8] was developed by making use of the solar cell block available in the Simscape library and connecting Current sensor and Voltage sensor across the solar cell block in series and parallel respectively as shown in figure 2.A PS constant block connected to its irradiation terminal provides irradiation to the cell which can be either constant or variable depending on the type of irradiation[5] we choose. Solver Configuration block is used to solve the equations of the solar cell. Current sensor and Voltage sensor show the output current and voltage of the cell respectively. Here, an important block used is PS S, which acts as an interface between Simscape and Simulink system library blocks.

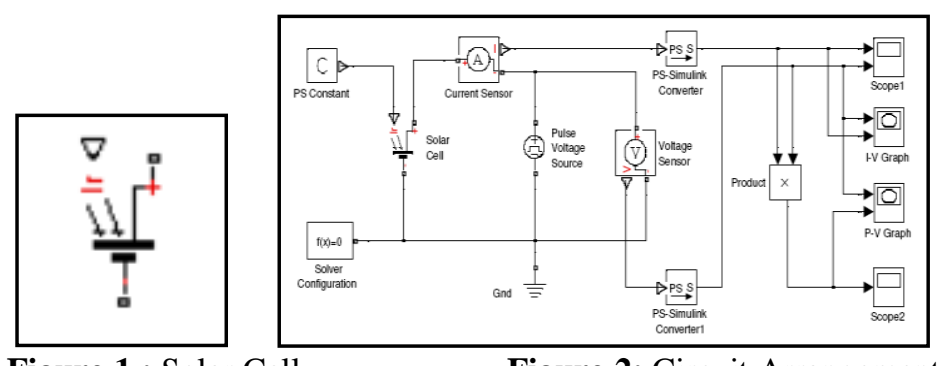

Figure 1 : Solar Cell

Figure 2: Circuit Arrangement

Thus, the scopes connected at the end would show us the voltage, current and power with respect to time. I-V and P-V characteristics of the solar cell are shown in figure $3 \& 4$. All parameters of solar cell is given in Table 1.

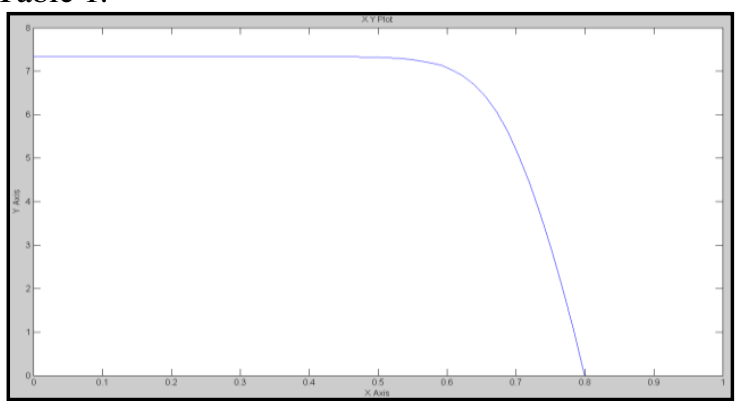

Figure 3: I-V curve

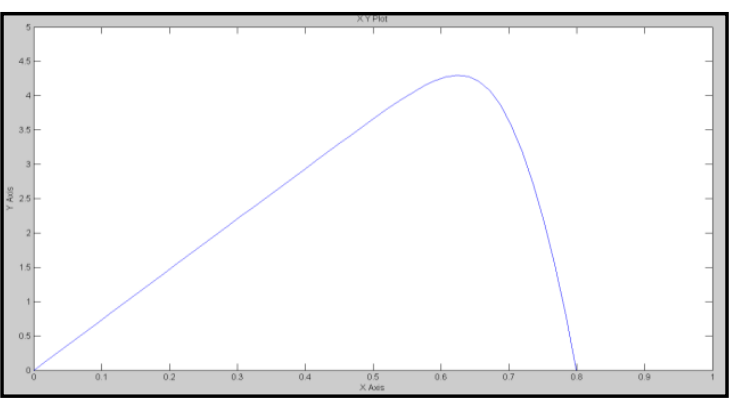

Figure 4: P-V curve

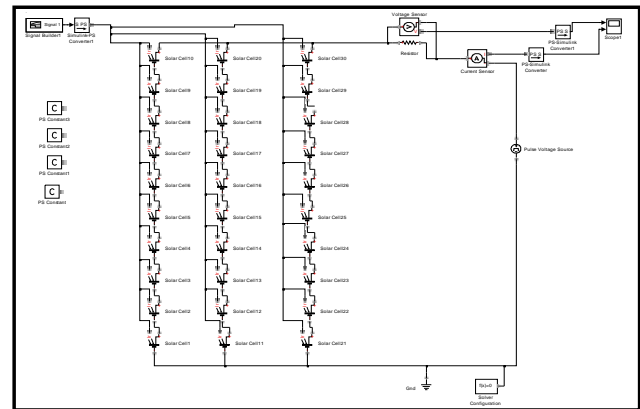

Figure 5: Solar Cell arrangement

Table 1: Solar Cell Model Specifications

\begin{tabular}{|c|c|}
\hline PARAMETER & PARAMETER VALUE \\
\hline Irradiance & Constant $1200 \mathrm{~W} / \mathrm{m}^{2}$ \\
\hline \multicolumn{2}{|l|}{ Solar Cell Parameters- } \\
\hline$>\quad$ Parameterize By & $\begin{array}{l}\text { By o/c voltage \& s/c current } \\
\text { parameter }\end{array}$ \\
\hline Open Circuit Voltage & $0.8 \mathrm{~V}$ \\
\hline \multirow{2}{*}{\multicolumn{2}{|c|}{ Short Circuit Current }} \\
\hline & \\
\hline \multicolumn{2}{|l|}{ Pulse Voltage Source- } \\
\hline Pulse Amplitude & $0.8 \mathrm{~V}$ \\
\hline Pulse Rise Time & $1 \mathrm{~s}$ \\
\hline Pulse Period & Inf \\
\hline Pulse Width & Inf \\
\hline
\end{tabular}




\section{PV Array}

Since the Output voltage from one PV cell is very insignificant to meet the loads, a PV array is made by connecting many such PV cells in series and parallel so as to achieve the desired voltage and current. The model of a PV array is shown in figure 5.This figure shows a basic subsystem model for the PV array which is made by connecting $10 \mathrm{PV}$ cell blocks in series and then connecting 3 such parallel branches together.

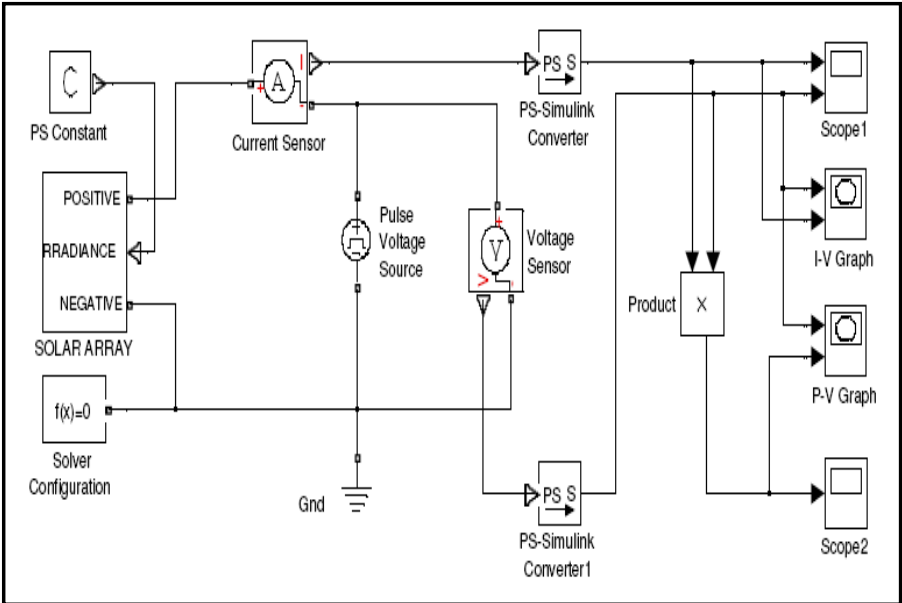

Figure 6: PV Array Model

Figure 6 shows the final PV array model made by connecting few more subsystem models in series, as we can see the modelling of PV array is same as that of PV cell and the same components are used. The I-V and $\mathrm{P}-\mathrm{V}$ characteristics of PV array are shown in figure 7 and 8 respectively. All parameters of solar array is provided in Table 2.

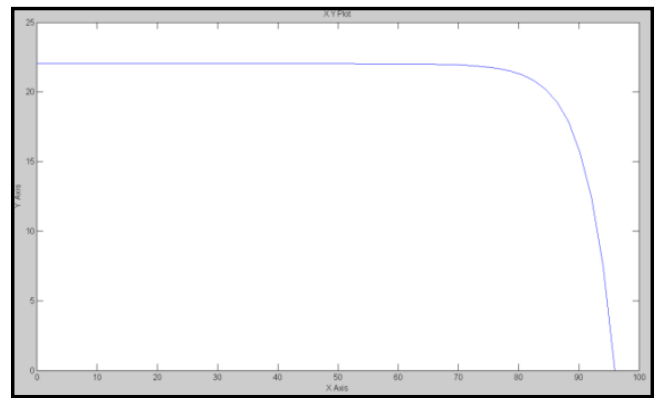

Figure 7: I-V Curve

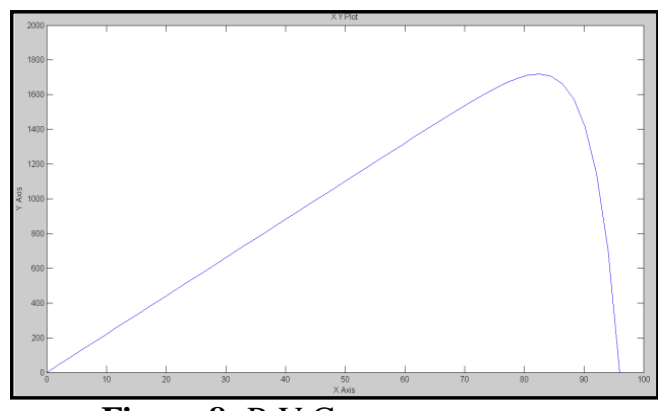

Figure 8: P-V Curve

Table 2: Model Specifications of PV Array

\begin{tabular}{|c|c|}
\hline PARAMETER & PARAMETER VALUE \\
\hline Irradiance & Constant $1000 \mathrm{~W} / \mathrm{m}^{2}$ \\
\hline $\begin{array}{ll}\text { Pulse Voltage Source Parameters- } \\
> & \text { Pulse Amplitude } \\
> & \text { Pulse Rise Time } \\
> & \text { Pulse Period } \\
> & \text { Pulse Width }\end{array}$ & $\begin{array}{l}96 \mathrm{~V} \\
1 \mathrm{~s} \\
\text { Inf } \\
\text { Inf }\end{array}$ \\
\hline $\begin{array}{ll}\text { Model Parameters- } \\
> & \text { No. of cells in series } \\
> & \text { No. of parallel paths } \\
& \text { Total no. of cells }\end{array}$ & $\begin{array}{l}120 \\
3 \\
360 \\
\end{array}$ \\
\hline $\begin{array}{ll}\text { Array } & \text { Output- } \\
& \text { Voltage } \\
& \text { Current }\end{array}$ & $\begin{array}{l}96 \mathrm{~V} \\
22.4 \mathrm{~A}\end{array}$ \\
\hline
\end{tabular}

\section{Maximum Power Point Tracker (MPPT)}

Maximum Power Point Tracking[5,6] is a technique used to extract the maximum power from PV cell or a PV array such that the cell would deliver power by operating at the maximum power point corresponding to its PV curve. A Photovoltaic Cell mainly acts as a constant current source and the Power delivered from or to a device is optimized where the derivative (graphically, the slope) $\mathrm{d} / \mathrm{dV}$ of the I-V curve is equal and opposite the $\mathrm{I} / \mathrm{V}$ ratio (where $\mathrm{dP} / \mathrm{dV}=0$ ). This is known as the Maximum Power Point (MPP) and corresponds to the 
"knee" of the curve. Maximum Power Point Trackers utilize different types of control circuit or logic to search for this point and thus to allow the converter circuit to extract the maximum power available from a cell.

The method that we used while designing MPPT[5,6] system is called as incremental conductance method which uses the PV array's incremental conductance $d I d V$ to compute the sign of $d P d V$. When $d I / d V$ is equal and opposite to the value of I/V (where $d P d V=0$ ) the algorithm knows that the maximum power point is reached and thus it terminates and returns the corresponding value of operating voltage for MPP.

$$
\mathrm{P}=\mathrm{V} * \mathrm{I}
$$

Differentiating w.r.t. voltage yields,

$$
\begin{aligned}
& \mathrm{dP} / \mathrm{dV}=\left(\mathrm{d}\left(\mathrm{V}^{*} \mathrm{I}\right)\right) / \mathrm{dV} \\
& \mathrm{dP} / \mathrm{dV}=\mathrm{I} * \mathrm{dV} / \mathrm{dV}+\mathrm{V}^{*} \mathrm{dI} / \mathrm{dV} \\
& \mathrm{dP} / \mathrm{dV}=\mathrm{I}+\mathrm{V}(\mathrm{dI} / \mathrm{dV})
\end{aligned}
$$

When the maximum power point is reached the slope $\mathrm{dP} / \mathrm{dV}=0$. Thus the condition would be,
$\mathrm{dP} / \mathrm{dV}=0$
$\mathrm{I}+\mathrm{V}(\mathrm{dI} / \mathrm{dV})=0$
$\mathrm{dI} / \mathrm{dV}=-\mathrm{I} / \mathrm{V}$
(7)

Flow Chart of Incremental Conductance Method is shown in figure 9 :

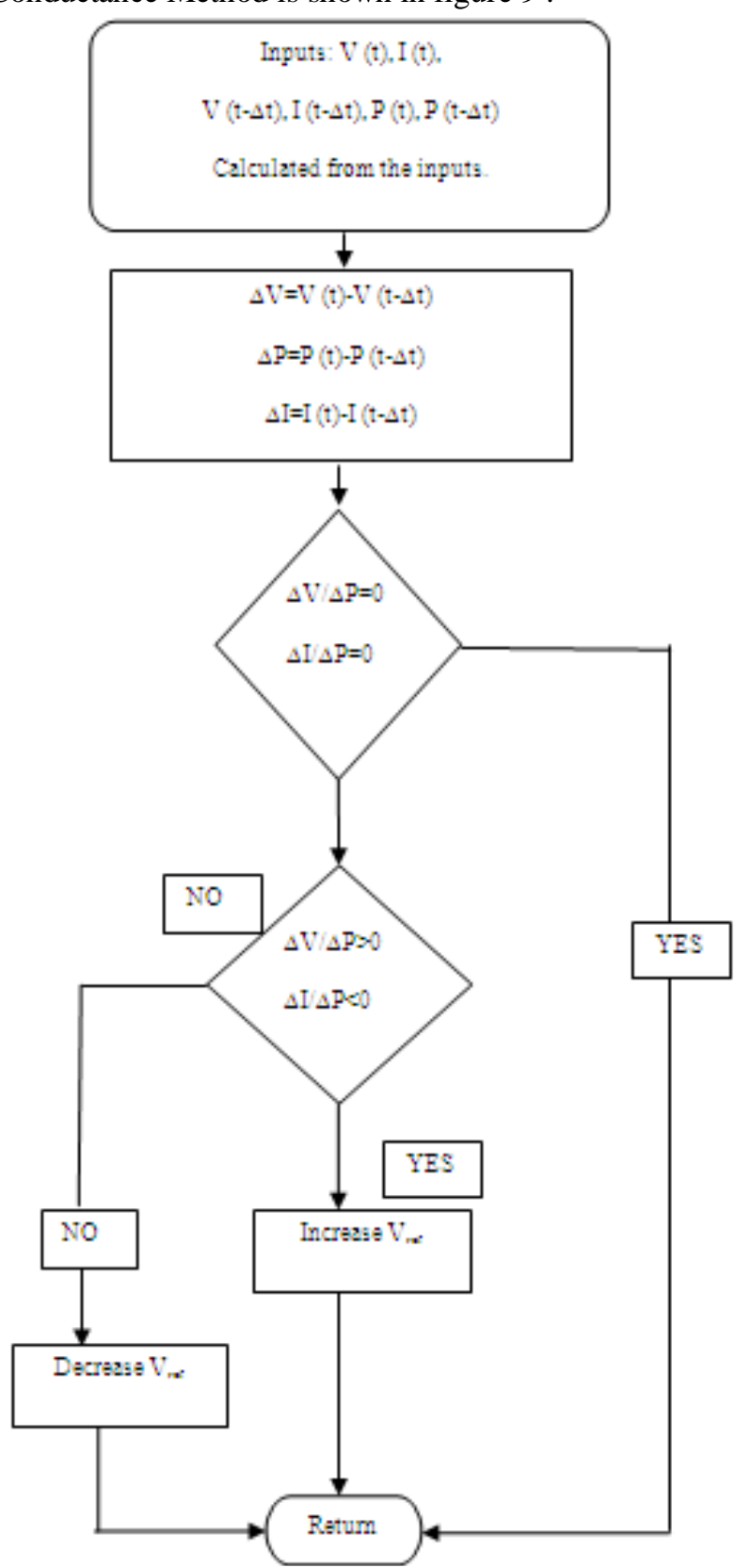

Figure 9: Flowchart of MPPT Controller 
The modelling of MPPT System is shown below. The program for incremental conductance method was written in the embedded function of the MATLAB.

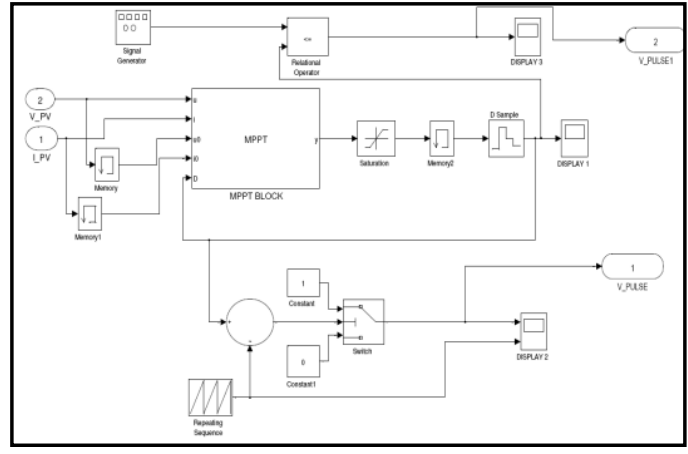

Figure 10: MPPT Model

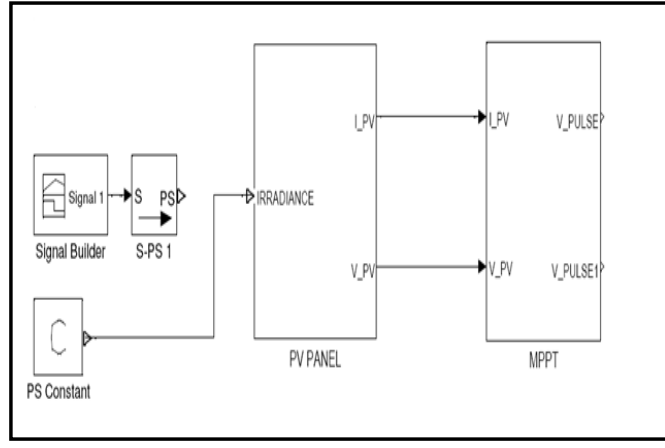

Figure11: Combined Model for MPPT and PV

Panel

The simulink model of MPPT controller is shown in figure 10 and its the combined model for MPPT and solar array is shown in figure11. The parameters for MPPT blocks are given in Table 3.

Table 3: Parameters of MPPT

\begin{tabular}{|c|c|}
\hline PARAMETER & PARAMETER VALUE \\
\hline \begin{tabular}{ll}
\multicolumn{2}{l}{ Saturation- } \\
$>$ & Lower Limit \\
$>$ & Upper Limit \\
\end{tabular} & $\begin{array}{l}0.4 \\
0.95\end{array}$ \\
\hline $\begin{array}{ll}\text { Signal Generator Parameters- } \\
> & \text { Wave Form } \\
> & \text { Amplitude } \\
> & \text { Frequency }\end{array}$ & $\begin{array}{l}\text { Square } \\
1 \mathrm{v} \\
10000 \mathrm{~Hz}\end{array}$ \\
\hline $\begin{array}{l}\text { Repeating Sequence } \\
\text { Parameters- } \\
\text { Time Values } \\
\quad \quad \text { Output }\end{array}$ & $\begin{array}{l}{\left[\begin{array}{ll}0 & 0.0001\end{array}\right]} \\
{\left[\begin{array}{ll}0 & 2\end{array}\right]}\end{array}$ \\
\hline
\end{tabular}

The output of the MPPT block i.e. duty ratio is given to the MOSFET of the Boost Converter to get boosted and regulated voltage from the solar array. The simulation model for boost converter and combined model for PV Array, MPPT and Boost converter are shown in figure 12 and 13. The output voltage waveform is shown in figure 14. The parameters of complete simulink model is shown in Table 4.

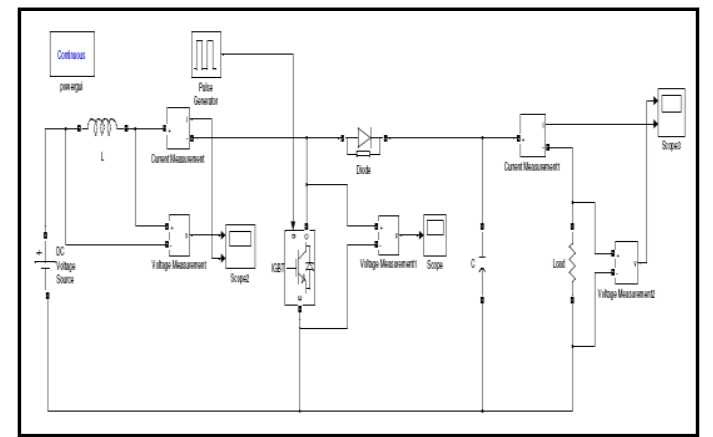

Figure 12: Boost Converter Model

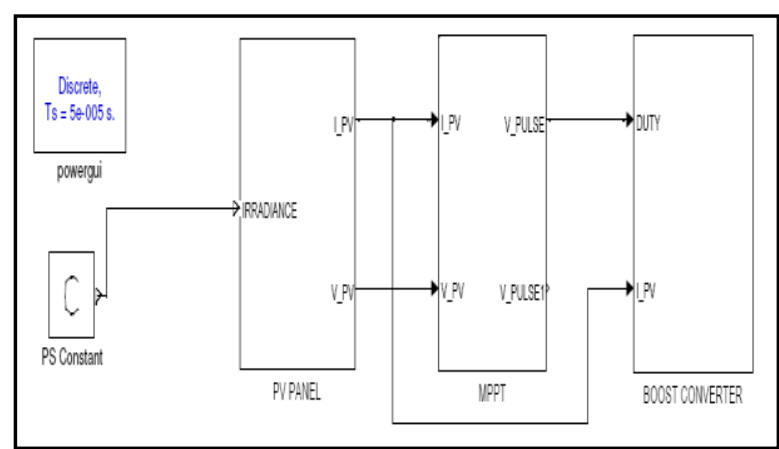

Figure 13: Combined Model

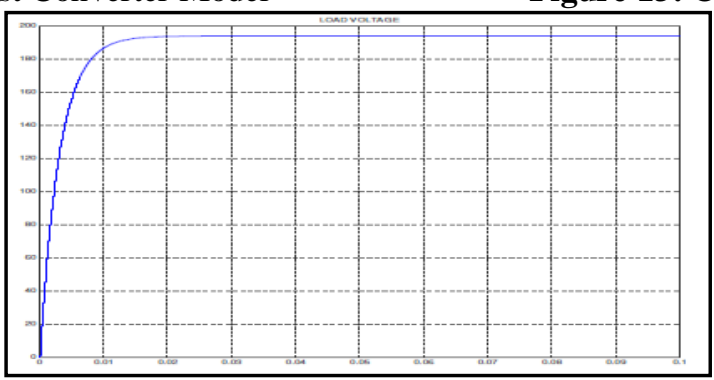

Figure 14: Load Voltage 
Table 4: Model Specifications of Combined Model

\begin{tabular}{|l|l|}
\hline PARAMETER & PARAMETER VALUE \\
\hline $\begin{array}{l}\text { Model Parameters- } \\
>\quad \text { Series Inductance } \\
>\quad \text { Capacitor }\end{array}$ & $0.001 \mathrm{H}$ \\
$>$ & $0.08 \mathrm{~F}$ \\
\hline Load Resistor & $10 \Omega$ \\
\hline $\begin{array}{l}\text { Output parameters- } \\
>\quad \text { Load Voltage }\end{array}$ \\
\hline
\end{tabular}

\section{Conclusion}

In this paper Simscape based model of solar cell and solar array is developed . Modelling of solar array in Simscape library is much easier than its modelling in Simulink environment of MATLAB. Boost converter is used to boost and regulate the output voltage of solar array . Duty cycle of boost converter is controlled through MPPT controller to track the maximum power from solar array. Simscape based models and their outputs of solar cell and array are shown clearly for different stages to understand the use of physical modelling using Simscape.

\section{Acknowledgements}

This research paper is made possible with the help and support from everyone of Electrical Engineering Department, JSS academy of Technical Education, Noida. I would also like to thank Mr. Aman kumar and Mr. Anant mathur ,B.Tech students(EE) for helping in publishing the above work.

\section{References}

[1] www.mathworks.com

[2] Huan-Liang Tsai, Ci-Siang Tu, and Yi-Jie Su, "Development of Generalized PhotovoltaicModel Using MATLAB/SIMULINK", 2008, Proceedings of the World Congress on Engineering and Computer Science

[3] H.Altas1, A.M. Sharaf, “A Photovoltaic Array Simulation Model for MATLAB/SIMULINK GUI Environment”, 2007, IEEE

[4] "Solar Cell Parameter Extraction from Data", MATLAB Help Demos.

[5] Sangita S. Kondawar,U. B. Vaidya,' A comparison of Two MPPT Techniques for PV System in MATLAB SIMULINK', Int. Journal of Engineering Research and Development, Vol 2, Issue 7 (Aug 2012), PP.73-79

[6] Samer Alsadi, Basim Alsayid,' Maximum Power Point Tracking Simulation for Photovoltaic Systems Using Perturb and Observe Algorithm', Int. Journal of Engineering and Innovative Technology, Vol. 2, Issue 6, December 2012.

[7] G. Venkateshwarlu, Dr. P. Sangameswar Raju,' Simscape Model of Photovoltaic Cell', Int. Journal of Advanced Research in Electrical, Electronics and Instrumentation Engineering, Vol.2, Issue 5, May 2013.

[8] Vandana Khanna, Bijoy Kishore Das, Dinesh Bisht,' MATLAB/SIMELECTRONICS Models based Study of Solar Cells', Int. Journal of Renewable Energy Research, Vol.3, No.1, 2013. 